\title{
Inhibitory Effect of Fermented Red Ginseng against Passive Cutaneous Anaphylaxis Reaction and Scratching behaviors in Mice
}

\author{
Eun-Ah Bae*, Hien-Trung Trinh*, Young-Chul Lee**, Sang-Wook Kim*** and Dong-Hyun Kim**\# \\ *Department of Food and Nutrition, Kyung Hee University, 1, Hoegi, Dongdaemun-ku, Seoul 130-701, Korea; \\ **Korea Food Research Institute, San 46-1, Baekhyun, Bundang-Ku, Seoungnam-Shi 463-420, Korea; \\ ***Kuan Zenlac Biotech Research Institute, Kuan Indutries Co., Ltd, Keumsan, Chungchunganam-Do, 312-911, Korea.
}

(Received January 17, 2008; Accepted February 17, 2008)

\begin{abstract}
Abtract : To evaluate the antiatopic effect of Korea red ginseng (RG, steamed root of Panax ginseng CA Meyer, Family Araliaceae) fermented by Bifidobacterium longum H-1 (FRG), its inhibitory effect on passive cutaneous anaphylaxis (PCA) reaction and itching in mice was measured. FRG and its ingredient saponin fraction (FSF) potently inhibited PCA reaction and scratching behaviors. FRG at a dose of $200 \mathrm{mg} / \mathrm{kg}$ and FSF at a dose of $50 \mathrm{mg} / \mathrm{kg}$ significantly inhibited the scratching frequency by $45 \%$ and $47 \%$, respectively. FRG and FSF also inhibited the degranulation and protein expression of tumor-necrosis factor- $\alpha$ and interleukin- 4 of RBL-2H3 cells induced by IgE-complex. However, polysaccharide fraction of FRG (FPF) weakly inhibited it, compared with FSF. The inhibitory effect of FRG against PCA reaction and scratching behaviors more potently inhibited than that of RG. Based on these findings, FRG can improve allergic skin disorders atopic dermatitis by the regulation of TNF- $\alpha$, and IL-4 produced by mast cells and basophils and its degranulation.
\end{abstract}

Key words : fermented red ginseng, scratching behaviors, passive cutaneous anaphylaxis, atopic dermatitis, allergy.

\section{INTRODUCTION}

Allergic diseases such as atopic dermatitis, asthma, allergic rhinitis, and food allergy afflict up to $20 \%$ of the human population in most countries ${ }^{1)}$. The etiology of allergy reactivity is based on IgE-medicated pharmacological processes of a variety of cell populations such as mast cell and basophils ${ }^{2}$. Degradation of mast cells and basophils with antigen-crosslinked IgE releases histamine, prostaglandins, leukotrines and cytokines affecting lymphocytes, macrophages, eosinophils and neutrophils. Finally cytokine-induced reaction causes tissue damages by allergic diseases, such as allergic rhinitis, atopic dermatitis, asthma and food allergies ${ }^{3-5}$. However, improving these diseases is very difficult. Therefore, herbal medicines have been advanced for allergic diseases, and their effectiveness has received increasing attention ${ }^{6}$.

Red ginseng (RG, the steamed root of Panax ginseng C.A. Meyer, family Araliaceae) is frequently used as a traditional medicine taken orally in Korea, China, Japan and Asian countries. The major components of ginseng

\footnotetext{
${ }^{\#}$ To whom correspondence should be addressed.

(Tel) +82-2-961-0374; (Fax) +82-2-957-5030

(E-mail)dhkim@khu.ac.kr
}

are ginsenosides and polysaccharides. ${ }^{7-8)}$ Many kinds of saponins, such as ginsenosides $\mathrm{Rb} 1, \mathrm{Rb} 2, \mathrm{Rc}$ and $\mathrm{Rf}$, have been isolated. However, RG contains genuine saponins, ginsenosides $\mathrm{Rg} 3$ and $\mathrm{Rh} 2^{9,10)}$. Ginsenosides $\mathrm{Rg} 3$ and $\mathrm{Rh} 2$ were produced from protopanaxadiol ginsenosides by steaming to prepare $R G^{11)}$. When $R G$ is fermented by Bifidobacterium $\mathrm{H}-1$, ginsenoside $\mathrm{Rg} 3$ is transformed to ginsenoside $\mathrm{Rh} 2$, which is a representative constituent in fermented RG $(F R G)^{12,13)}$. These ginsenosides have been reported to show various biological activities including anti-inflammatory activity, antiallergic, endothelium-independent aorta relaxation and anti-tumor effects. ${ }^{14-17)} \mathrm{Com}-$ pared to ginsenoside $\mathrm{Rg} 3$, ginsenoside $\mathrm{Rh} 2$ exhibits potent cytotoxicity against tumor cells, antiallergic effect against mast cells and antiinflammatory activity in microglial cells ${ }^{13,18,19)}$. Sugiyama et al. reported that ginsenoside Rg3 suppressed histamine release from mast cells caused due to stimulation with compound 48/80 in vitro ${ }^{20)}$. We reported that red ginseng exhibited antiallergic effect ${ }^{21)}$. We also reported the antiallergic and antiinflammatory effect of $\mathrm{RG}$ and ginsenoside $\mathrm{Rh} 1^{22,23)}$, antiallergic and passive cutaneous anaphylaxis reaction (PCA)-inhibitory effects of compound $\mathrm{K}^{23)}$ and the ginsenoside Rh2 more potently inhibited the PCA reaction ${ }^{6}$. 
However, antiatopic effects, such as PCA reaction scratching behavior reactions, of FRG and its ingredients saponins fraction (FSF) and polysaccharide fraction (FPF) have not been thoroughly studied.

Therefore, the present study is to investigate the inhibitory effect of FRG, FSF and FPF on passive cutaneous anaphylaxis reaction and itching in mice.

\section{MATERIALS AND METHODS}

\section{Materials}

p-Nitrophenyl-N-acetyl- $\beta$-D-glucosaminide, Freund's complete adjuvant, anti-dinitrophenol (DNP)-IgE, DNPhuman serum albumin (HSA), Evans blue, trichloroacetic acid, betamethasone, and azelastine were purchased from Sigma Chemical Co. (U.S.A). FRG water extract was prepared according to the previous method of Trinh et al. ${ }^{15)}$. The FSF and FPF were isolated according to the previous reported methods ${ }^{15,16)}$.

\section{Animals}

The male ICR mice (20-25 g) were supplied from the Orient Co., Ltd, a branch of Charles River Laboratories (Seoul, Korea). All animals were housed in wire cages, maintained at $20-22^{\circ} \mathrm{C}$ and $50 \pm 10 \%$ humidity, fed standard laboratory chow (the Orient Co., Ltd), and allowed water ad libitum. All procedures relating to the animals and their care conformed to the international guidelines: 'Principles of Laboratory Animals Care' (NIH publication no. 85-23, revised 1985) and the Animal Care and Use Guidelines of Kyung Hee University, Korea.

\section{Passive Cutaneous Anaphylaxis (PCA) Reaction}

An IgE-dependent cutaneous reaction was measured according to the previous method of Choo et al. ${ }^{24)}$ The male ICR mice (25-30 g) were injected intradermally with $10 \mu \mathrm{g}$ of anti-DNP IgE into each of two dorsal skin sites that had been shaved $48 \mathrm{~h}$ earlier. The sites were outlined with a water-insoluble red marker. Forty-eight hours later each mouse received an injection of $200 \mu \mathrm{l}$ of $3 \%$ Evans blue PBS containing $200 \mu \mathrm{g}$ of DNP-HSA via the tail vein. The test agents were administered $1 \mathrm{~h}$ prior to DNPHSA injection. Thirty min after DNP-HSA injection, the mice were sacrificed and their dorsal skins were removed for measurement of the pigment area. After extraction with $1 \mathrm{ml}$ of $1.0 \mathrm{~N} \mathrm{KOH}$ and $4 \mathrm{ml}$ of a mixture of acetone and $0.6 \mathrm{~N}$ phosphoric acid (13:5), the amount of dye was determined colorimetrically (the absorbance at $620 \mathrm{~nm}$ ).

\section{Assay of scratching behavior frequency}

The scratching behavioral experiment in male mice was performed according to the method of Sugimoto et al. ${ }^{25}$ ) Briefly, the mice were placed in acrylic cages $(22 \times 22 \times$ $24 \mathrm{~cm}$ ) and allowed to acclimatize for about $10 \mathrm{~min}$. The rostral part of the skin on the back of the mice was clipped, and $300 \mu \mathrm{g} / 50 \mu \mathrm{l}$ of histamine in ICR mice then intradermally injected into each mouse. Immediately after the intradermal injection, the mice (one animal/cage) were placed back in the same cage, and the scratching behavior was recorded using an 8-mm video camera (SV-K80, Samsung, Seoul, Korea). The scratching frequency of the injected site with the hind paws was counted for $60 \mathrm{~min}$. The test agents were orally administered $1 \mathrm{~h}$ before the scratching agent.

Assay of inhibitory activity against $\beta$-hexosaminidase release of $\mathrm{RBL}-2 \mathrm{H3}$ cells

The inhibitory activity of test agents against the release of $\beta$-hexosaminidase from RBL-2H3 cells was evaluated according to Choo et al. ${ }^{24)}$. RBL-2H3 cells were grown in Dulbecco's modified Eagle Medium supplemented with $10 \%$ fetal bovine serum and L-glutamine. Before the experiment, cells were dispensed into 24 -well plates at a concentration of $5 \times 10^{5}$ cells per well, and using a medium containing $0.5 \mu \mathrm{g} / \mathrm{ml}$ of mouse monoclonal $\operatorname{IgE}$, the cells were sensitized by incubation overnight at $37^{\circ} \mathrm{C}$ in $5 \% \mathrm{CO}_{2}$. They were then washed with $500 \mathrm{ml}$ of Siraganian buffer ( $\mathrm{pH} 7.2,119 \mathrm{mM} \mathrm{NaCl}, 5 \mathrm{mM} \mathrm{KCl}, 0.4$ $\mathrm{mM} \mathrm{MgCl}, 25 \mathrm{mM}$ PIPES, $40 \mathrm{mM} \mathrm{NaOH}$ ) and incubated in $160 \mu \mathrm{l}$ of Siraganian buffer containing $5.6 \mathrm{mM}$ glucose, $1 \mathrm{mM} \mathrm{CaCl}$ and $0.1 \% \mathrm{BSA}$ for additional 10 $\min$ at $37^{\circ} \mathrm{C}$. The cells were exposed to $40 l$ of test agents for $20 \mathrm{~min}$, treated with 201 of antigen (DNP-HSA, $1 \mu \mathrm{g}$ / $\mathrm{ml}$ ) for $10 \mathrm{~min}$ at $37^{\circ} \mathrm{C}$ to activate cells and to evoke allergic reactions. The reaction was stopped by cooling in an ice bath for $10 \mathrm{~min}$. The reaction mixture was centrifuged at $2000 \mathrm{rpm}$ for $10 \mathrm{~min}$ and $25 \mu \mathrm{l}$ aliquots of the supernatant were transferred to 96 well plates and incubated with $25 \mu \mathrm{l}$ of substrate $(1 \mathrm{mM}$ p-nitrophenyl-N-acetyl- $\beta$-D-glucosaminide) for $1 \mathrm{~h}$ at $37^{\circ} \mathrm{C}$. The reaction was stopped by adding $200 \mu \mathrm{l}$ of $0.1 \mathrm{M} \mathrm{Na} \mathrm{CO}_{3} / \mathrm{NaHCO}_{3}$. Absorbance was measured by using an ELISA reader at $405 \mathrm{~nm}$.

\section{Enzyme-Linked Immunosorbent Assay (ELISA) of IL-4 and TNF- $\alpha$ in RBL-2H3 Cells Stimulated by IgE- antigen Complex \\ RBL-2H3 cells $\left(5 \times 10^{5}\right.$ cells $)$, previously cultured in} DMEM, were treated with $0.5 \mu \mathrm{g} / \mathrm{ml}$ of mouse monoclonal IgE to sensitize the cells. The cells $(1.8 \mathrm{ml})$ were 
exposed to $0.2 \mathrm{ml}$ of the test agents (dissolved in $0.5 \%$ dimethyl sulfoxide) for $4 \mathrm{~h}$, followed by treatment with $0.2 \mathrm{ml}$ DNP-HSA $(1 \mu \mathrm{g} / \mathrm{ml})$ for $40 \mathrm{~min}$ at $37^{\circ} \mathrm{C}$. The supernatant $(50 \mu \mathrm{l})$ was transferred to 96-well ELISA plates, and the IL- 4 and TNF- $\alpha$ concentrations then determined using commercial ELISA kits (Pierce Biotechnology, Inc., Rockford, IL, USA).

\section{Statistics}

All the data were expressed as the mean \pm standard deviation, and statistical significance was analyzed by one way ANOVA followed by Student-Newman-Keuls test.

\section{RESULTS}

\section{Inhibition of FRG on PCA reaction and scratching behaviors}

To evaluate the antiallergic effect of FRG, the inhibitory effect of FRG against mouse PCA reaction induced by the intradermal injection of anti-DNP-HSA and DNP-HSA was investigated (Table 1). FRG extract potently inhibited PCA reaction, and at doses of 100 and $200 \mathrm{mg} / \mathrm{kg}$ inhibited PCA reaction by 30 and $45 \%$, respectively. Therefore, we fractionated FSF and FPF from FRG and investigated their PCA reaction-inhibitory effect. The FSF potently inhibited the PCA reaction, but the FPF weakly exhibited the PCA reaction-inhibitory effect.

Next, we measured the inhibitory effects of FRG and its ingredients on compound 48/80-induced scratching behaviors in mice. FRG and its FSF potently inhibited scratching

Table 1. Inhibitory effects of fermented red ginseng (FRG) and its ingredients on passive cutaneous anaphylaxis reaction in mice

\begin{tabular}{ccc}
\hline \hline Agent & Dose $(\mathrm{mg} / \mathrm{kg})$ & Inhibition $^{\mathrm{a})}(\%)$ \\
\hline FRG & 100 & $30 \pm 4^{\mathrm{c}}$ \\
& 200 & $45 \pm 6^{\mathrm{c}, \mathrm{d}}$ \\
FSF & 25 & $32 \pm 6^{\mathrm{c}, \mathrm{d}}$ \\
& 50 & $47 \pm 7^{\mathrm{c}, \mathrm{d}}$ \\
FPF & 25 & $14 \pm 1^{\mathrm{b}}$ \\
& 50 & $24 \pm 4^{\mathrm{c}}$ \\
Azelastine & 10 & $71 \pm 19^{\mathrm{e}}$ \\
\hline
\end{tabular}

a) The amounts of extravasated Evan blue from the dorsal skin $(1 \times 1 \mathrm{~cm})$ of the control stimulated with the IgE-antigen complex and vehicle-treated groups were $23 \pm 3$ and $8 \pm 2 \mu \mathrm{g}$, respectively. Each experiment consisted of six observations. All inhibitory values indicate mean \pm S.D.

b,c,d,e Those with the same letter are not significantly different in each column $(P<0.05)$. behaviors (Table 2). However, FPF did not inhibit it. FRG at a dose of $200 \mathrm{mg} / \mathrm{kg}$ and FSF at a dose of $50 \mathrm{mg} / \mathrm{kg}$ significantly inhibited the scratching frequency by $48 \%$ and $47 \%$, respectively.

\section{Inhibitory activity of FRG and its ingredients against degranulation of $\mathrm{RBL}-2 \mathrm{H3}$ cells}

To understand the inhibitory mechanism of FRG against PCA reaction and scratching behaviors, their inhibitory effect against $\beta$-hexosaminidase release (degranulation) of

Table 2. Inhibitory effects of FRG and its ingredients on the scratching behaviors induced by histamine in mice

\begin{tabular}{ccc}
\hline \hline Agent & Dose $(\mathrm{mg} / \mathrm{kg})$ & Inhibition $^{\mathrm{a})}(\%)$ \\
\hline FRG & 100 & $36 \pm 5^{\mathrm{d}}$ \\
& 200 & $48 \pm 6^{\mathrm{e}}$ \\
FSF & 25 & $32 \pm 4^{\mathrm{d}}$ \\
& 50 & $47 \pm 6^{\mathrm{e}}$ \\
FPF & 25 & $-\mathrm{b})$ \\
& 50 & $12 \pm 6^{\mathrm{c}}$ \\
Azelastine & 10 & $62 \pm 5^{\mathrm{f}}$ \\
\hline
\end{tabular}

All agents were administered p.o. prior to compound histamine. Each experiment consisted of six observations. All inhibitory values indicate mean \pm S.D.

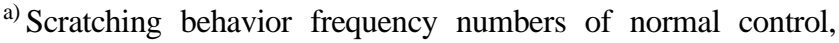
which was treated with saline alone, and control group, which was treated with compound 48/80 histamine and saline, for $1 \mathrm{~h}$ were $235 \pm 21$ and $3 \pm 2$, respectively.

b) Not determined.

c,d,e,f Those with the same letter are not significantly different in each column $(P<0.05)$.

Table 3. Inhibitory effects of FRG and its ingredients on the $\beta$ hexosaminidase release from RBL $2 \mathrm{H} 3$ cells induced by IgE-antigen complex

\begin{tabular}{cc}
\hline \hline Agent & $\mathrm{IC}_{50}(\mathrm{mg} / \mathrm{ml})$ \\
\hline FRG & $>0.2(22)$ \\
FSF & 0.19 \\
FPF & $>0.2(11)$ \\
Azelastine & 0.02 \\
\hline
\end{tabular}

RBL-2H3 cells, which were grown in DMEM supplemented with $10 \%$ fetal bovine serum and L-glutamine, were dispensed into 24 well plates, at a concentration of $5 \times 10^{5}$ cells per well, and sensitized using $0.5 \mu \mathrm{g} / \mathrm{ml}$ of mouse monoclonal IgE. They were then washed with $500 \mu \mathrm{l}$ of siraganian buffer, exposed to test agents for $20 \mathrm{~min}$, and treated with $20 \mu \mathrm{l}$ of antigen (DNP-HSA, $1 \mu \mathrm{g} / \mathrm{ml}$ ) for $10 \mathrm{~min}$ at $37^{\circ} \mathrm{C}$. The release of $\beta$-hexosaminidase from RBL-2H3 cells was measured according to the method of Choo et al. ${ }^{18)}$

The values in parenthesis indicate degranuation-inhibitory percent at a dose of $0.2 \mathrm{mg} / \mathrm{ml}$. 
RBL-2H3 cells induced by IgE-antigen complex was investigated (Table 3). FRG and FSF inhibited the degranulation of RBL-2H3 cells. However, FPF did not inhibit it. Among them, SF most potently inhibited it.

\section{Inhibition of FRG and its ingredients on cytokine production of RBL-2H3 cells}

The effects of FRG and its ingredients against TNF- $\alpha$ and IL-4 protein expressions were also measured in RBL$2 \mathrm{H} 3$ cells stimulated by IgE-antigen complex by the analysis of ELISA analysis (Fig. 1). FRG and its ingredients reduced protein expression of TNF- $\alpha$ and IL- 4 , showing
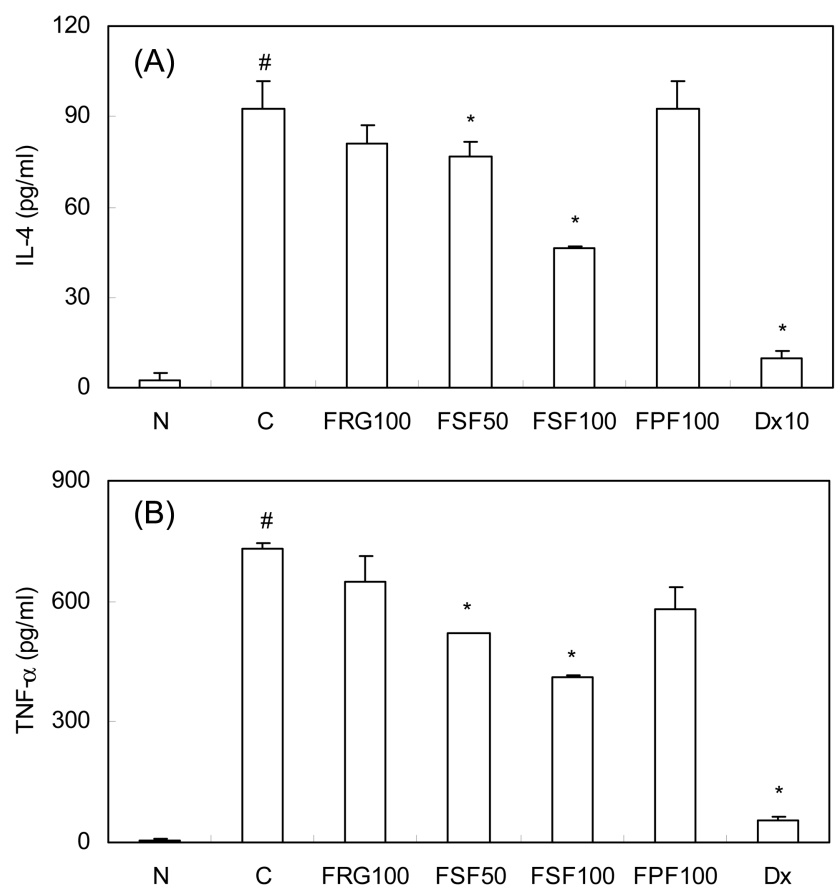

Fig. 1. Effect of red ginseng and its ingredients on the protein expression of TNF- $\alpha$ and IL- 4 in RBL-2H3 cells induced by IgE-antigen complex. RBL- $2 \mathrm{H} 3$ cells $\left(5 \times 10^{5}\right.$ cells $)$ were treated with $0.5 \mu \mathrm{g} / \mathrm{mL}$ of mouse monoclonal $\mathrm{IgE}$ for $1 \mathrm{~h}$, then exposed to $0.2 \mathrm{~mL}$ of the test agents $(\mathrm{N}$, normal; C, vehicle alone; FRG100, $100 \mu \mathrm{g} / \mathrm{ml}$ FRG; FSF50, $50 \mu \mathrm{g} / \mathrm{ml} \mathrm{FSF;} \mathrm{FSF100,} 100 \mu \mathrm{g} / \mathrm{ml} \mathrm{FSF;} \mathrm{FPF100,}$ $100 \mu \mathrm{g} / \mathrm{ml} \mathrm{FP.F;} \mathrm{D \times 10,} 10 \mu \mathrm{M}$ dexamethasone) for 20 min, followed by treatment with $0.2 \mathrm{~mL}$ dinitrophenolhuman serum albumin (DNP-HSA, $1 \mu \mathrm{g} / \mathrm{mL}$ ) for $4 \mathrm{~h}$ at $37^{\circ} \mathrm{C}$, and the performance of ELISA for IL-4 (A) and TNF- $\alpha(B)$. Then normal group $(\mathrm{N})$ was treated with the vehicle alone, while the control group $(\mathrm{C})$ was treated with the vehicle and IgE-antigen complex. Values represent the mean \pm S.D. for duplicate experiments. Inhibition values indicate the mean \pm S.D. $(n=3)$.

"Significantly different, compared with the normal $(P<0.05)$. *Significantly different, compared with the control $(P<0.05)$. most strong reduction in case of FSF.

\section{DISCUSSION}

Red ginseng is prepared by the steaming and drying of fresh ginseng. The major components of fresh ginseng are ginsenosides Rb1, Rb2, Rc, Rf, Rg1 and Re and those of $\mathrm{RG}$ are genuine saponins, ginsenosides $\mathrm{Rg} 3$ and $\mathrm{Rh} 2$ transformed from ginsenoside Rb1, Rb2, Rc, etc ${ }^{9,10)}$. Fermented red ginseng also contains ginsenoside $\mathrm{Rg} 3$ and $\mathrm{Rh} 2$. However, the ratio of these ginsenosides $\mathrm{Rg} 3$ and $\mathrm{Rh} 2$ between red ginseng and fermented red ginseng is different, because the ginsenoside $\mathrm{Rg} 3$ in red ginseng is transformed to ginsenoside $\mathrm{Rh} 2$ by the fermentation of lactic acid bacteria. Fermentation produces beneficial products for humans. Therefore, fermentation has been used for their manufacture on an industrial scale. These processes are performed by beneficial and healthful microbes. These microbes transform some components of foods as well as convert sugars to alcohol and lactic acid. For example, lactic acid bacterial fermentation of ginseng produces lactic acid as well as compound $\mathrm{K}$, which is transformed from ginsenoside $\mathrm{Rb} 1, \mathrm{Rb} 2$ and $\mathrm{Rc}$ and exhibits the potent cytotoxicity against tumor cells ${ }^{26}$.

When RG is fermented by Bifidobacterium $\mathrm{H}-1$, ginsenoside Rg3 is transformed to ginsenoside $\mathrm{Rh} 2$, which exhibits potent cytotoxicity against tumor cells, antiallergic effect against mast cells and antiinflammatory activity in microglial cells ${ }^{13,18,19)}$. We also reported that the antiallergic and anti-inflammatory effect of $\mathrm{RG}^{22,23,27)}$, and the ginsenoside $\mathrm{Rh} 2$ more potently inhibited the PCA reaction ${ }^{14)}$. However, antiatopic effect such as PCA reaction scratching behavior reactions, of FRG has not been thoroughly studied. Therefore, in the present study, the antiallergic effect of FRG and its ingredients FSF and FPF was investigated. FRG and its PSF potently inhibited PCA reaction induced by IgE-antigen complex and compound 48/80-induced scratching behaviors. These inhibitory activities were more potent than those of red ginseng. FSF inhibited the release of $\beta$-hexosaminidase from RBL$2 \mathrm{H} 3$ cells. The previous study, the inhibitory effects of ginsenoside Rh2 against PCA reaction and scratching behaviors were more potent than those of ginsenoside Rg3. This result suggests that the potent antiallergic effect of FRG may be due to the higher content of ginsenoside Rh2 in fermented red ginseng than in red ginseng. The previous studies reported that ginsenoside Rh1, compound K and ginsenoside $\mathrm{Rh} 2$ showed more potent membrane stabilizing effect than those of disodium cromoglycate ${ }^{14,15,24)}$. 
These results suggest that the inhibitory action of these ginsenosides on the release of $\beta$-hexosaminidase may be due to protection of the cytolytic response by antigen-IgE and these ginsenosides after all showed the most potent inhibitory activity on PCA reaction. FRG and its FSF also potently inhibited the scratching behaviors (itching) induced by histamine. Itching, which provokes the desire to scratch, can be local or widespread and associated with atopic dermatitis, uriticaria or systemic disorders (cholestasis, uraemia). Many endogenous chemical agents, like amines, proteases, growth factors, neuropeptides, opioids, ecosanoids and cytokines, can act as pruritogens ${ }^{28,29}$. Scratching can cause skin lesions and contribute to severe psychological disturbances ${ }^{30)}$, and therefore, inhibition of this response is consistently beneficial for improving the quality of life.

FRG, particularly FSF, significantly inhibited protein expression of proinflammatory TNF- $\alpha$ and IgE-inducing IL-4 in RBL-2H3 cells induced by IgE-antigen complex. However, these inhibitions are not inconsistent with in vivo antiallergic effects. These findings suggest that FRG can improve allergic skin disorders atopic dermatitis and contact dermatitis by the regulation of TNF- $\alpha$ and IL- 4 production in mast cells and basophils as well as their membrane stabilization. Therefore, we believe that FRG can show extensive antiallergic effect and its FSF can be a candidate for the therapeutic agent for allergy.

\section{ACKNOWLEGEMENT}

This work was supported by the grant from the Korean Society of Ginseng (2006).

\section{REFERENCES}

1. Bachert, C. and van Cauwenberge, P.: The WHO ARIA (allergic rhinitis and its impact on asthma) initiative. Chem. Immunol. Allergy, 82, 119-26 (2003).

2. Stevens, R. L. and Austen, K.F. : Recent advances in the cellular and molecular biology of mast cells. Immunology Today 10, 381-386 (1989).

3. Sakuma, S., Higashi, Y., Sato, N., Sasakawa, T., Sengoku, T., Ohkubo, Y., Amaya, T., and Goto, T. : Tacrolimus suppressed the production of cytokines involved in atopic dermatitis by direct stimulation of human PBMC system (Comparison with steroids). Int. Immunopharmacol. 1, 1219-26 (2001).

4. Schafer-Korting, M., Schmid, M. H., and Korting, H. C. : Topical glucocorticoids with improved risk-benefit ratio. Drug Safety. 14, 375-385 (1996).
5. Simons, F. E. R.: The antiallergic effects of antihistamines (H1-receptor antagonists). J. Allergy Clin. Immunol. 90, 705715 (1992).

6. Belory, L. : Complementary and alternative interventions in asthma, allergy, and immunology. Ann. Allergy Asthma Iтmunol, 93(2 Suppl 1), S45-54 (2004).

7. Tanaka, N., Tanaka, O. and Shibata, S. : Chemical studies on the oriental plant drugs. XXVIII. Saponins and sapogenins of ginseng; Stereochemistry of sapogenin of ginsenoside Rb1, Rb2 and Rc. Chem. Pharm. Bull., 20, 1212-1216 (1972).

8. Wu, J. Y., Gardner, B. H., Murphy, C. I., Seals, J. R., Kensil, C. R., Recchia, J., Beltz, G. A., Newman, G. W., Newman, M. J. : Saponin adjuvant enhancement of antigen-specific immune responses to an experimental HIV-1 vaccine. $J$. Immunol., 148, 1519-1525 (1992).

9. Kitagawa, I., Yoshikawa, M., Yoshihara, M., Hayashi, T. and Taniyama, T. : Chemical studies on crude drug precession. I. On the constituents of ginseng radix rubura (I). Yakugaku Zasshi 103, 612-622 (1983).

10. Kown, S. W., Han, S. B., Park, I. H., Kim, J. M., Park, M. K. and Park, J. H. : Liquid chromatographic determination of less polar ginsenosides in processed ginseng. J. Chromatogr. A, 921, 335-339 (2001).

11. Kim, W. Y., Kim, J. M., Han, S. B., Lee, S. K., Kim, N. D., Park, M. K., Kim, C. K., Park, J. H. : Steaming of ginseng at high temperature enhances biological activity. J. Nat. Prod. 63, 1702-1704 (2000).

12. Bae, E. A., Kim, N.-Y., Han, M. J., Choo, M.-K. and Kim, D.-H. : Transformation of ginsenosides to compound $\mathrm{K}$ by lactic acid bacteria of human intestine J. Microbiol. Biotechnol. 13, 9-14 (2000).

13. Bae, E. A., Han, M. J., Choo, M. K., Park, S. Y., and Kim, D.-H. : Metabolism of 20(S)- and 20(R)-ginsenoside Rg3 by human intestinal bacteria and its relation to in vitro biological activities. Biol. Pharm. Bull. 25,58-63 (2002).

14. Park, E. K., Choo, M. K., Han, M. J., Kim, D. H., Ginsenoside Rh1 possesses antiallergic and anti-inflammatory activities. Int. Arch. Allergy Immunol. 133, 113-120 (2004)

15. Kim, N. D., Kang, S. Y., Kim, M. J., Park, J. H., SchiniKerth, V. B.: The ginsenoside Rg3 evokes endotheliumindependent relaxation in rat aortic rings: role of $\mathrm{K}+$ channels. Eur J Pharmacol., 367, 51-57 (1999)

16. Bae, E. A., Han, M. J., Choo, M. K., Park, S. Y. and Kim, D. H. : Metabolism of 20(S)- and 20(R)-ginsenoside Rg3 by human intestinal bacteria and its relation to in vitro biological activities. Biol. Pharm. Bull., 25, 58-63 (2002).

17. Nakata, H., Kikuchi, Y., Tode, T., Hirata, J., Kita, T., Ishii, K., Kudoh, K., Nagata, I. and Shinomiya, N. : Inhibitory effects of ginsenoside Rh2 on tumor growth in nude mice bearing human ovarian cancer cells. Jpn J. Cancer Res., 89, 733-740 (1998). 
18. Mochizuki, M., Yoo, C. Y., atsuzawa, M. K., Sato, K., Saiki, I., Tono-oka, S., Samukawa, K. and Azuma, I. : Inhibitory effect of tumor metastasis in mice by saponins, ginsenoside $\mathrm{Rb} 2,20(\mathrm{R})$ - and 20(S)-ginsenoside Rg3, of Red ginseng. Biol. Pharm. Bull. 18, 1197-1202 (1995).

19. Tanaka, N., Tanaka, O. and Shibata, S. : 1972. Chemical studies on the oriental plant drugs. XXVIII. Saponins and sapogenins of ginseng; Stereochemistry of sapogenin of ginsenoside Rb1, Rb2 and Rc. Chem. Pharm. Bull. 20, 12121216.

20. Tachikawa, E., Kudo, K., Harada, K., Kashimoto, T., Miyate, Y., Kakizaki, A. and Takahashi, E. : Effects of ginseng saponins on responses induced by various receptor stimuli. Eur. J. Pharmacol., 369, 23-32 (1999).

21. Trinh, H. T., Bae, E. A., Han, M. J., Shin Y. W. and Kim D.H. : Inhibitory effects of red ginseng on passive cutaneous anaphylaxis and scratching behavior reactions in mice. $J$. Ginseng Res., 31, 137-141 (2007).

22. Bae, E. A., Han, M. J., Shin, Y. W. and Kim, D. H. : Antiallergic and antipsoriatic effects of Korean Red ginseng. $J$. Ginseng Res., 29, 80-85 (2005).

23. Park, E. K., Choo, M. K., Han, M. J. and Kim, D.-H. : Ginsenoside Rh1 possesses antiallergic and anti-inflammatory activities. Int. Arch. Allergy Immunol., 133, 113-120 (2004).

24. Choo, M. K., Park, E. K., Han, M. J. and Kim, D.-H. : Antiallergic activity of ginseng and its ginsenosides. Planta Med., 69, 518-522 (2003).

25. Sugimoto, Y., Umakoshi, K., Nojiri, N. and Kamei, C. : Effect of histamine H1 receptor antagonists on compound 48/80induced scratching behavior in mice. Eur. J. Pharmacol., 351, 1-5 (1998).

26. Bae, E. A., Kim, N. Y., Han, M. J., Choo, M. K. and Kim D.$\mathrm{H}$. : Transformation of ginsenosides to compound $\mathrm{K}$ by lactic acid bacteria of human intestine. J. Microbiol. Biotechnol., 13, 9-14 (2003).

27. Trinh, H. T., Bae E. A., Han M. J., Shin, Y. W. and Kim, D. H. : Inhibitory effects of red ginseng on passive cutaneous anaphylaxis and scratching behavior reactions in mice. $J$. Ginseng Res., 31, 137-141 (2007).

28. Lerner, E. A. : Chemical mediator of itching. In: Berhard, J., editor. Itch: mechanisms and management of pruritis. New York: McGraw-Hill; p.23-25 (1944).

29. Hagermark, O. : Itch mediators. Semin Dermatol., 14, 271276 (1955)

30. Raid, D. S. : Pruritis of chronic cholestasis. Q. J. Med., 88, 603-607 (1955). 